\title{
Bilayer Electrolyte Thin Films Gadolinia Doped Ceria /Yttria Stabilized Zirconia Prepared by Pulsed Laser Deposition for Electrochemichal Devices
}

\begin{abstract}
ROVENA VERONICA PASCU*
National Institute For Laser Plasma And Radiation P.O. Box Mg 07, 077125, Măgurele, Romania

In this paper bilayer thin films of 10CGO/8YSZ electrolyte with enhanced $O^{2-}$ conductivity composed of gadolinia doped $\mathrm{CeO}_{2}\left(\mathrm{Ce}_{0,9} \mathrm{Gd}_{0,1} \mathrm{O}_{2-\delta}\right)$ and yttria stabilized zirconia 8 mol\% $\mathrm{Y}_{2} \mathrm{O}_{3}$ doped $\mathrm{ZrO} 2$ layers were deposited by Pulsed Laser Deposition (PLD) using various numbers of pulses. This composite has supplementary function in electrochemical devices because 10 CGO can act as interdiffusion barrier with cathode materials. The structure and morphology of these thin films, having thicknesses smaller than $1 \mu \mathrm{m}$, were investigated by X-ray diffraction (XRD), scanning electron microscopy (SEM) and atomic force microscopy (AFM). The XRD patterns exhibit cubic fluorite structure with a sharp (111) peak. The grain size was found to depend on the thickness. Optical characterization was carried out by spectroscopic ellipsometry (SE) using the Tauc-Lorentz model.
\end{abstract}

Keywords: Laser ablation, Electrolytes, Bilayer Thin Films, Tauc - Lorentz Model, Electrochemical Fuel Cells Devices

Thin films of high-k dielectric ceramics $10 \mathrm{CGO} / 8 \mathrm{YSZ} / \mathrm{Pt} / \mathrm{Si}$ with $\mathrm{O}^{2-}$ conductivity deposited by Pulsed Laser Deposition [1] have been studied in this work for applications in miniaturized planar electrochemical devices, like ceramic multilayer oxygen lambda sensor and $\mu$ SOFC (Micro Solid Oxide Fuel Cell) [2]. Unlike 8YSZ also 10CGO preserve fluorite structure over the whole range temperature from room temperature to the melting point at $2400^{\circ} \mathrm{C}$. Due to the fact that performance is theoretically influenced by operating temperature and in order to overcome such constrains, it can be exploited the advantages of low resistivity and maximization of $\mathrm{O}^{2-}$ conductivity of these thin films by doping $\mathrm{ZrO}_{2}$ with $8 \mathrm{~mol} \% \quad \mathrm{Y}_{2} \mathrm{O}_{3}$. Other methods include the development of composite bilayer thin films electrolytes $10 \mathrm{CGO} / 8 \mathrm{YSZ}$ based on the higher $\mathrm{O}^{2-}$ conductivity thin films. The $\mathrm{CGO}$ films ensure the higher ionic conductivity, most be dense and crack free necessary for high gas blockage and have very high mechanical strength to enlarge the time life of micro electrochemical devices; lower operating temperature $\left(<500^{\circ} \mathrm{C}\right)$ reduced the costs of materials and improves durability. In the low operating temperature, 10CGO thin films exhibit higher oxygen conductivity (one order of magnitude higher) than $8 \mathrm{YSZ}$ thin films because the ionic radius of $\mathrm{Gd}^{3+}(0.105 \mathrm{~nm})[5]$ is very close to the host cation $\mathrm{Ce}^{4+}(0.108 \mathrm{~nm})$. At the same time, the ionic transference of CGO [6] expands as the operating temperature decrease, being larger than 0.9 at $\mathrm{T}<500^{\circ} \mathrm{C}$. Our study is focused on developing bilayer electrolyte $10 \mathrm{CGO} / 8 \mathrm{YSZ}$ thin films for operation in low temperature $\mathrm{T}<500^{\circ} \mathrm{C}$ with $\mathrm{CGO}$ acting like a blocking layer for interdiffusion with cathode made of $\mathrm{La}_{x} \mathrm{Sr}_{1-x} \mathrm{Co}_{y} \mathrm{Fe}_{1-y} \mathrm{O}_{3-\delta}$ (LSCF). In classical configuration with 8 YSZ thin films electrolyte perovskite like cathode react with YSZ leading to the formation of two insulating phases by segregation of $\mathrm{Sr}$ and $\mathrm{La}$ which destabilized the cathode electrolyte interference. To avoid a rapid deterioration of 8YSZ electrolytes, a dense 10CGO is deposited between $\mathrm{La}_{x} \mathrm{Sr}_{1-x} \mathrm{Co}_{y} \mathrm{Fe}_{1-y} \mathrm{O}_{3-\delta}$ (LSCF) and YSZ to prevent a chemical reaction. But CGO electrolyte exposed to reduction atmosphere on anode side exhibit mixed ionic and electronic conductivity (MIEC) caused by reduction of $\mathrm{Ce}^{4+}$ to $\mathrm{Ce}^{3+}$ with influence on the global efficiency of electrochemical device by lowering the open circuit voltage and decreases the power output. For inhibiting chemical reaction of CGO and electrical leakage, YSZ can be placed on anode side. High density electrolyte 10CGO/8YSZ can be achieved regularly by sintering at $\mathrm{T}>1400^{\circ} \mathrm{C}$ that generated larger grains, crakes and interdiffusion. Good quality of 10CGO, $8 \mathrm{YSZ}$ and 10CGO/8YSZ have been fabricated by techniques such as spin coating [8], spray pyrolysis [9], chemical solution deposition [10], dry press [11] and e-beam [12].

Pulsed Laser Deposition (PLD) is used for the deposition of novel thin films having a variety of functionalities and complex compositions, like 10CGO and 8YSZ, by optimizing the control parameters [1, 9, 13, 14]. PLD is the best technological research tool to prepare thin films having extremely pure phases because it allows a good stoichiometric transfer from target to substrate, without contamination. PLD can be used to grow planar ceramic multicomponent thin films and assure a good reproductibility and homogeneity. 
Bilayer electrolyte 10CGO/8YSZ greatly reduces the ohmic and polarized resistance, and increased the electrochemical performance by blocking the diffusion of components from LSCF in the YSZ structure acting like a barrier layer. The microstructure of 10CGO/8YSZ thin films can be controlled by laser fluence, number of pulses, oxygen partial pressure, distance between target and substrate, substrate temperature. The thickness also influences the grain size on the rule $\mathrm{h}$ to $\mathrm{h}^{2 / 5}$ [14]. The structural and morphological characterization of the thin films was carried out by XRD, SEM and AFM. Optical data is acquired by variable spectroscopic ellipsometry VWASE for investigation of the dielectric properties, roughness and thickness.

\section{Experimental part}

\section{Materials and methods}

The 10 CGO target was synthesized from commercially $\mathrm{Ce}_{0.90} \mathrm{Gd}_{0.10} \mathrm{O}_{1.95}$ nanocrystalline powder using a Pechini method. Ce $\left(\mathrm{NO}_{3}\right)_{3} \cdot 6 \mathrm{H}_{2} \mathrm{O}$ (Sigma-Aldrich) and $\mathrm{Gd}\left(\mathrm{NO}_{3}\right)_{3} \cdot 6 \mathrm{H}_{2} \mathrm{O}$ (Sigma-Aldrich) like precursors, while citric acid (CA) (monohydrate, Sigma-Aldrich), and ethylene glycol (EG) (anhydrous, Sigma-Aldrich) were used as complexation and polymerization agents, respectively. The following molar ratios were used: $\mathrm{CA}: \mathrm{Me}=4.5$ and $\mathrm{CA}: \mathrm{EG}=2$. The removal of the excess solvent led to a gel. After gel drying overnight at $180^{\circ} \mathrm{C}$, a solid resin was obtained. The solid resin was calcined in air at $550^{\circ} \mathrm{C}$ for $5 \mathrm{~h}$ and the mixed solid oxide was thus obtained. In order to prepare the target, the solid oxide powder was uniaxially pressed in a $10 \mathrm{~mm}$ diameter stainless steel die and the asobtained pellet was further sintered at $1300^{\circ} \mathrm{C}$ for $10 \mathrm{~h}$. The $8 \mathrm{YSZ}$ target with $14 \mathrm{~mm}$ diameter x $5 \mathrm{~mm}$ thick was manufactured by American Elements (SUA) by sintering powder of 99, 99\%Zirconia and 8mol\% Yttria -Stabilized. The deposition of bilayer 10CGO/8YSZ/Pt/Si (111) thin films was performed on CompexPro 50 Pulsed Laser Deposition equipment using $\operatorname{ArF}$ excimer laser $(\lambda=193 \mathrm{~nm})$ with energy of $230 \mathrm{~mJ}_{\text {pulse }}{ }^{-1}$ and repetion rate $v=30 \mathrm{~Hz}$, fluence $\varphi=5 \mathrm{~J} / \mathrm{cm}^{2}$, in oxygen partial pressure of $8 \times 10^{-2} \mathrm{mbar}$, the laser beam was focused at an angle of incidence of $45^{\circ}$ on YSZ and CGO targets. Two sets of experiments were made by using Pt/Si (111) substrates (15 x $\left.15 \mathrm{~mm}\right)$ at $600^{\circ} \mathrm{C}$ and $50 \mathrm{~mm}$ distance target- substrates with variation of number of pulses and time of depositions sample (a) $(90.000 ; 50 \mathrm{~min} / 90.000 ; 50 \mathrm{~min})$ and sample (b) $(70.000 ; 39 \mathrm{~min} / 140.000 ; 78 \mathrm{~min})$ for $10 \mathrm{CGO} / 8 \mathrm{YSZ} / \mathrm{Pt} / \mathrm{Si}$ bilayer configuration. The vacuum chamber has a base pressure $6 \times 10^{-4} \mathrm{mbar}$ for sample (a) and $7 \times 10^{-4} \mathrm{mbar}$ for sample (b) by operating a turbo pump. (Fig.1)

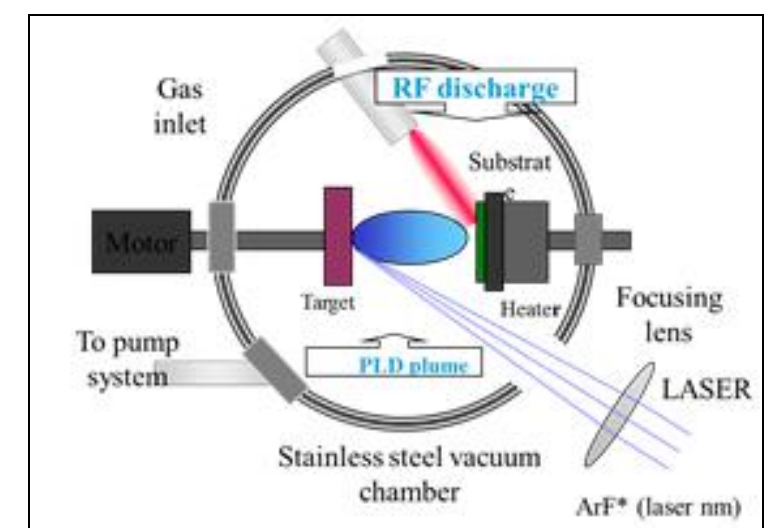

Fig. 1. A schematic diagram of the pulse laser deposition setup

The XRD measurements have been performed by using a Panalytical X'Pert PRO MRD diffractometer equipped with monochromatic X-ray radiation of $\mathrm{CuK} \alpha 1(0.154056 \mathrm{~nm})$ in Bragg- Bretano geometry with $2 \theta$ in the angular range $15-75^{\circ}$, scanned in steps of $0.02^{\circ}$ with an acquisition time of $0.2 \mathrm{~s} / \mathrm{step}$. The Joint Committee on Powder Diffraction Standards (JCPDS) database from the International Center for Diffraction Data (ICDD) was utilized for structural characterization like phase identification, crystalline dimensions and lattice constance.

The Scanning Electron Microscope (SEM) manufactured by FEI - SEM FEI Inspect $S$ is designed to investigate the surface quality and cross - section for thickness measurements of bilayer 10CGO/8YSZ/ Pt/Si (111).

Atomic Force Microscopy (AFM) XE-100 Park Systems is used to characterization the morphology and Root Means Square (RMS) roughness, in non-contact mode; allows a maximum horizontal scan area of about $50 \times 50 \mu \mathrm{m}^{2}$ and a vertical movement up to $12 \mu \mathrm{m}$. The investigated areas were $2 \times 2 \mu \mathrm{m}^{2}, 5 \times 5 \mathrm{~m}^{2}, 10 \times 10 \mu \mathrm{m}^{2}$ and $20 \times 20 \mu \mathrm{m}^{2}$, for revealing both the general aspect of the samples as well as their topographic details. 
Spectroellipsometer WVASE with variable angels of incidence $\left(60^{\circ}-70^{\circ}\right)$ is used for optical characterization, having high accuracy and precision with a wide spectral range 250-1700nm. Optical models a generated by WVASE32 software; $n, k$ parameters and roughness are measured. The equipment is assisted by WVASE32 software necessary for generation the optical models and fitting the ellipsometers Psi $(\Psi)$ and delta $(\Delta)$ parameters.

\section{Results and discussions}

The XRD characterization of 8 YSZ and 10CGO ceramic targets is shown in Fig. 1. This is necessary to identify the crystalline structure that will be transfer on the substrate. Also, the characterization of the bilayer thin films of $10 \mathrm{CGO} / 8 \mathrm{YSZ} / \mathrm{Pt} / \mathrm{Si}$ (100) is presented in relation to the same diagrams for identification of crystalline phases. The (111) crystalline phases are cubic phase, and are identified using the standard base XRD JSCPDS file 089-9069.

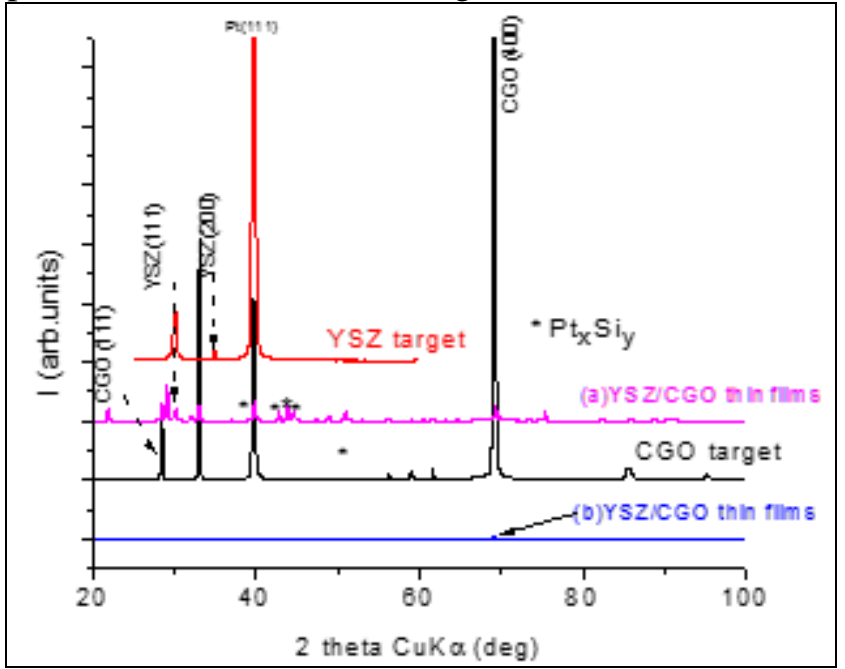

Fig.2. XRD spectra of the two targets YSZ and CGO and bilayers $\mathrm{CGO} / \mathrm{YSZ} / \mathrm{Pt} / \mathrm{Si}$ (111) films. The diffractograms shows the films are crystalline and fluorite cubic structures

The average crystallite sizes were calculated at the peak position of the (111) reflection $\left(2 \theta=40^{\circ}\right)$, a strongly preferential orientation. The spectra indicate that the deposited films have polycrystalline structure, with lattice constants $\mathrm{a}=0.5134 \mathrm{~nm}$ (YSZ) film (a) and $\mathrm{a}=0.4923 \mathrm{~nm}$ for film (b) respectively. From the XRD pattern for films (b) it was observed also a reflection for (400) that indicated the polycrystalline structure of both samples. From Table 1 it is observed that the values of lattice constants for CGO/YSZ thin films and YSZ target are very close, due to the role of $\mathrm{Y}$ in stabilizing the cubic structure. The doping with Ce leads to a small difference in the mean dimension of particles, with an effect on crystalline order that will influence optical characterization (Table 1). The influence of the $\mathrm{Pt} / \mathrm{Si}$ substrate is also appearing in Figure 2.

Table 1

THE VALUE OF LATTICE PARAMETER AND MEAN DIMENSION FOR CRYSTALLITES FOR 10CGO, 8YSZ AND 10CGO/8YSZ TARGETS AND THIN FILMS

\begin{tabular}{|c|c|c|c|c|c|}
\hline \multirow[t]{2}{*}{ Sample and target } & \multirow{2}{*}{$\begin{array}{c}\text { Substrate } \\
\text { type }\end{array}$} & \multicolumn{2}{|c|}{ YSZ phase } & \multicolumn{2}{|c|}{ CGO phase } \\
\hline & & $\begin{array}{c}\text { Lattice parameter } \\
\text { a (nm) }\end{array}$ & $\begin{array}{c}\text { Crystallite dimension } \\
\text { D (nm) }\end{array}$ & $\begin{array}{c}\text { Lattice parameter } \\
\text { a (nm) }\end{array}$ & $\begin{array}{c}\text { Crystallite } \\
\text { dimension } D(n m)\end{array}$ \\
\hline YSZ & Target & 0.5155 & 18 & & \\
\hline CGO & Target & & & 0.54230 & 71 \\
\hline $\mathrm{CGO} / \mathrm{YSZ}$ (a) & $\mathrm{P} / \mathrm{Si}$ & 0.5134 & 24 & 0.5426 & 41 \\
\hline $\mathrm{CGO} / \mathrm{YSZ}(\mathrm{b})$ & $\mathrm{Pt} / \mathrm{Si}$ & 0,4923 & 20 & 0.5020 & 39 \\
\hline $\begin{array}{c}\mathrm{ZrO}_{2} \text {-cubic } \\
\text { Standard JCPDS } \\
(089-9069)\end{array}$ & & 5,1350 & & & \\
\hline
\end{tabular}


In figure 2 show the surface morphology of the 10CGO/8YSZ film deposited on Pt/Si (111) substrates using various number of pulses and deposition times, generating variable RMS (Root Mean Square Roughness) of $34.6 \mathrm{~nm}$ and $19.2 \mathrm{~nm}$, respectively, which are related to the PLD process parameters. Atomic Force Microscopy images [15] show fairly smooth surfaces and demonstrate that they are composed of nanoscale grains with distinct shape and particle distribution. The surface morphologies of the two bilayer films is changed with the local sites, dimensions of windows of exploration $\left(2 \times 2 \mu \mathrm{m}^{2}\right),\left(5 \times 5 \mu \mathrm{m}^{2}\right),\left(10 \times 10 \mu \mathrm{m}^{2}\right)$ and $\left(20 \times 20 \mu \mathrm{m}^{2}\right)$, with a variation in RMS; this can be like a base for selecting PLD parameters for development more functional structures.

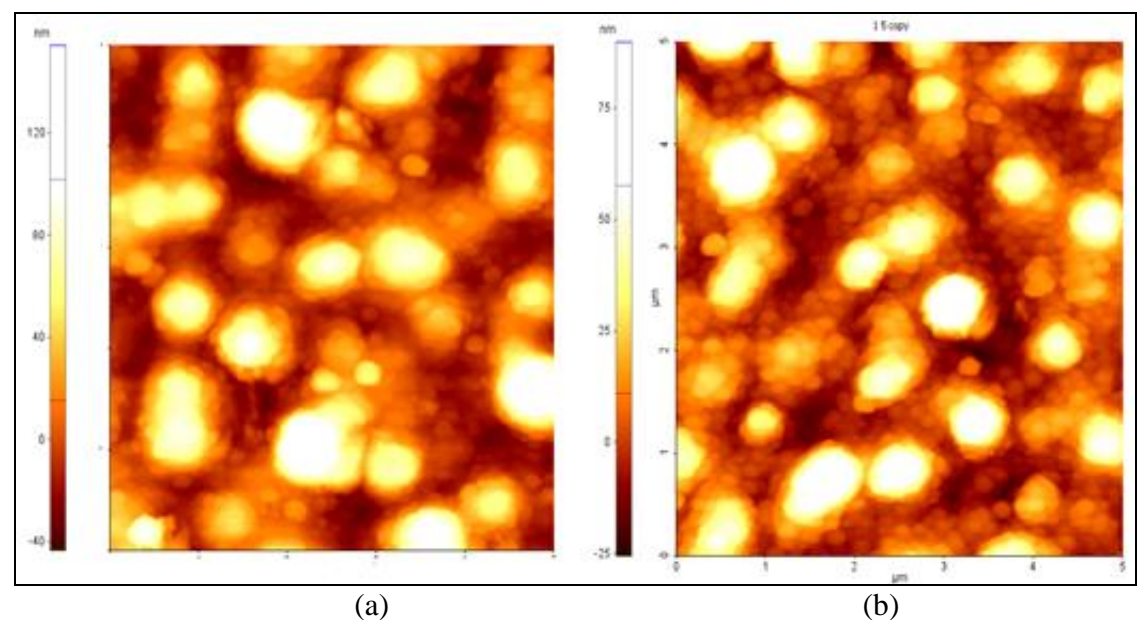

Fig.3. Atomic Force Microscopy images (2D) $5 \times 5 \mu \mathrm{m}^{2}$ areas of bilayer 10CGO/8YSZ deposited on $\mathrm{Pt} / \mathrm{Si}$ (111) deposited at $600{ }^{\circ} \mathrm{C}$ at different number of pulses with variable RMS: a) 34,600 nm; b) $19.054 \mathrm{~nm}$

The surface morphology and cross section of the films are presented in figures $3 a$ and $3 b$. From the top view it is observed the influence of the deposition parameters in obtaining stable thin films, free of cracks and small droplets; small particles have been obtained on sample (b). Cross- section micrographs indicate different thickness of $140.1 \mathrm{~nm}$ for 10CGO and $510.0 \mathrm{~nm}$ for total thickness of sample (a) and $205.1 \mathrm{~nm}$ for $10 \mathrm{CGO}$ and $615.0 \mathrm{~nm}$ for total thickness of sample (b). Both bilayers thin films are dense, columnar and crack free. Micrograph image obvious shows a better distribution of crystallites with influence of roughness and uniformity.

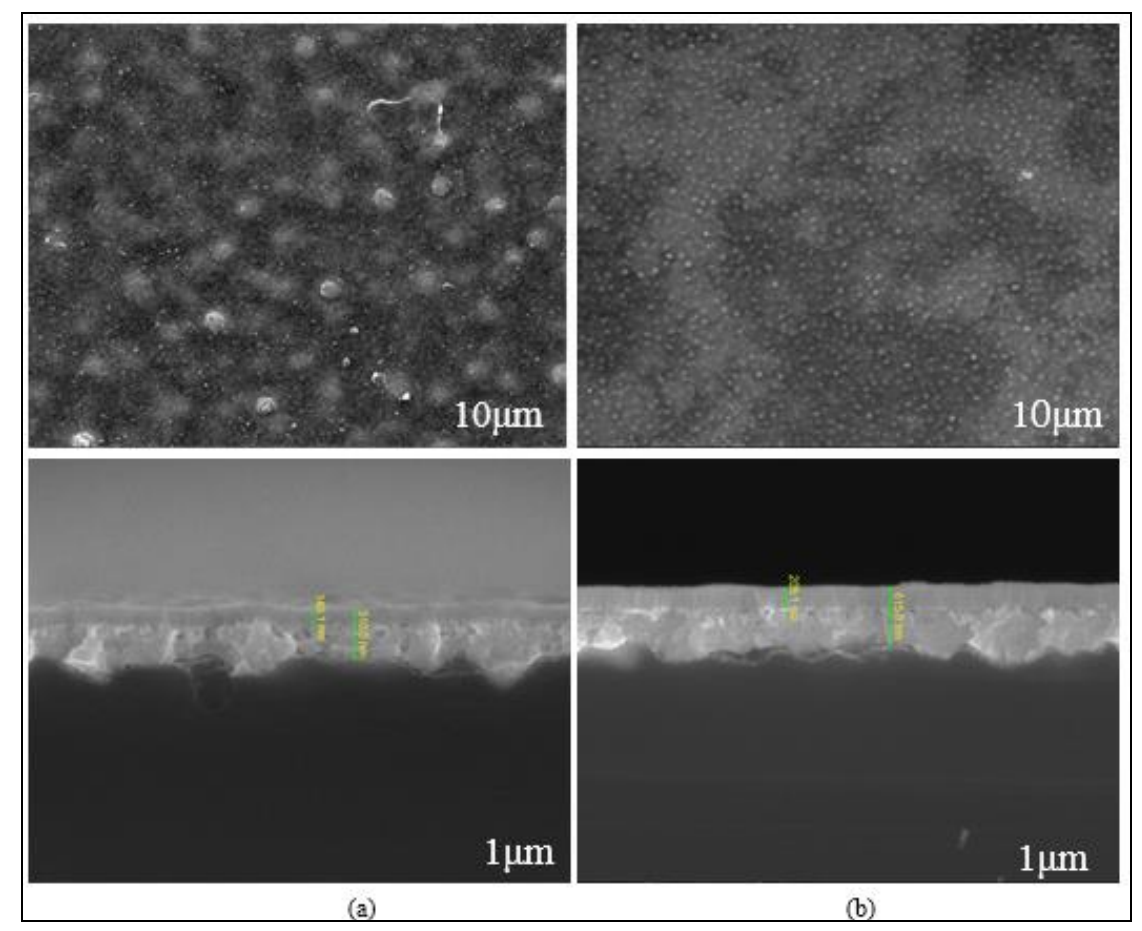

Fig.4. Top views of microstructures and cross-section of samples (a) and (b) 
High - k ceramic electrolyte 8YSZ thin films are transparent over a large range of the spectrum; $\mathrm{CeO}_{2}$ has a higher refractive index and high absorption mainly in ultraviolet (UV) radiation [16]. The substitution of Ce with Gd generates a significant effect on the coefficient of absorption $[2,17]$. In the operating range $(250-1700 \mathrm{~nm})$, optical characterizations were made using a VVASE (Variable Angle Spectroscopic Ellipsometry) (Woollam, SUA) assisted by the WVASE 32 software package for processing ellipsometric parameters $\Psi$ and $\Delta$ acquired at three angles of incidence $\left(60,65\right.$ and $\left.70^{\circ}\right)$ based on an optical model [16]. Because 10CGO/8YSZ/Pt/Si produces a different absorption caused by interdiffusion effects, crystallite size and microstructure, Cauchy - Urbach laws are not sufficient to describe the model. As a result, an advanced Tauc -Lorentz dispersion model based on general oscillator (GenOsc) was selected to an accurate representation of absorption feature bellow the band gap, very important aspect for sensor design $[18,19]$. These aspects demonstrate the complexity of our bilayerstructures.
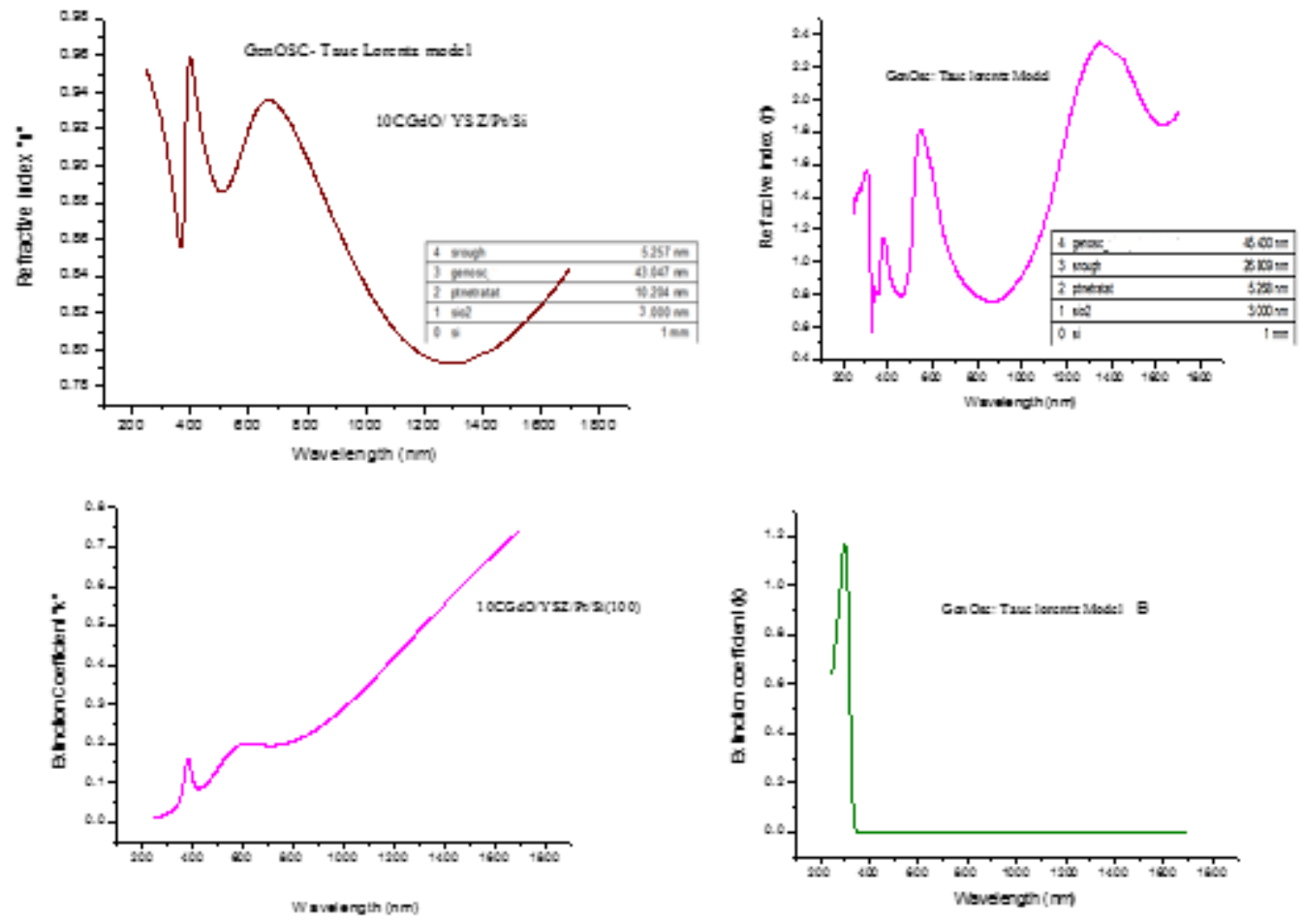

Fig. 5. Variation of refractive and extinction coefficients as a function of $(\lambda)$ for 10CGO/8YSZ/ Pt/Si thin films for Tauc Lorentz oscillator

In table 2 it is presented the roughness measured by SE and RMS measured by AFM like a comparative study. The difference in measurements is generated by the fundamental principles of SE and AFM. SE measures the effect of roughness at the level of atomic dimensions; RMS roughness is influenced of the peak to valley heights being about two times larger than SE measurements.

Table 2

SURFACE ROUGHNESS MEASURED BY SE AND AFM ON BILAYER 10CGO/8YSZ/PT/SI DEPOSITED AT $600^{\circ} \mathrm{C}$

\begin{tabular}{|c|c|c|c|c|c|c|c|c|}
\hline \multirow[t]{2}{*}{ Sample } & \multirow{2}{*}{$\begin{array}{c}\text { Deposition } \\
\text { temperature } \\
\left({ }^{\circ} \mathrm{C}\right)\end{array}$} & \multirow{2}{*}{$\begin{array}{l}\text { Roughness } \\
\text { measured } \\
\text { by } \mathrm{SE}(\mathrm{nm})\end{array}$} & \multicolumn{4}{|c|}{ RMS roughness AFM (nm) } & \multirow{2}{*}{$\begin{array}{c}\text { Thickens } \\
\text { nonuniformity } \\
(\%)\end{array}$} & \multirow[t]{2}{*}{ MSE } \\
\hline & & & $2 \times 2 \mu m^{2}$ & $5 \times 5 \mu m^{2}$ & $10 \times 10 \mu m^{2}$ & $20 \times 20 \mu m^{2}$ & & \\
\hline Sample A & 600 & 5.257 & 29.3 & 34.6 & 32.825 & 81.156 & 8.452 & 435 \\
\hline Sample B & 600 & 26.809 & 19.231 & 19.054 & 20.856 & 22.208 & 60.464 & 525 \\
\hline
\end{tabular}

\section{Conclusions}

In this report it was investigated structural and optical characterization of the bilayer $10 \mathrm{CGO} / 8 \mathrm{YSZ} / \mathrm{Pt} / \mathrm{Si}$ thin films deposited by PLD with variable number of pulses. The aim is to use PLD like a reproductible technique suited for application in manufacturing planar ceramics micro electrochemical devices like $\mu$ SOFC and $\lambda$ oxygen sensors. By tuning control parameters for PLD it was possible to deposit dense columnar, free cracks and voids bilayer 10CGO/8YSZ/ Pt/Si thin films as desired for solid electrolytes. 
A novelty is the implementation of a GenOsc (Tauc Lorentz) optical model necessary for a better calculation of absorption mainly in UV spectra.

Acknowledgements: This work has been financed by the National Authority for Research an Innovation in the Frame of Nucleus Programme. The author thanks George Epurescu, Andreea Andrei for AFM measurements, Catalin Luculescu for SEM measurements.

\section{References}

1. B. ARNDT, H. NOEI, T. F. KELLER, P. MÜLLER, V. VONK, A. NENNING, A. K. OPITZ, J. FLEIG, U. RÜTT, A. STIERLE, Thin Solid Films, 603, 2016, p. 56-61

2. G. CONSTANTIN, C. ROSSIGNOL, J.P. BARNES, E. DJURADO, SOLID STATE IONICS, 235, 2013, p. 36-41

3. W. WU, Z. ZHAO, X. ZHANG, Z. LIU, D. CUI, B. TU, D. OU, Electrochemistry Communications 71, 2016, p. 43-47

4. M. Z. KHAN, M. T. MEHRAN, R. H. SONG, J.W. LEE, S. B. LEE, T. H.LIM, S. J. PARK, Ceramics International 42, 2016, p. 6978-6984 5. B. MORENO, R. F. GONZALEZ, J. R. JURADO, A. MAKRADI, P. NUNEZ, E. CHINARRO, International Journal of Hydrogen Energy 39, 2014, p. 5433-5439

6. M. ZUBAIRKHAN, M. T. MEHRAN, R. H. SONG, J.W. LEEA, S. B. LEE, T. H. LIM, S. J. PARK, Ceramics International 42, 2016 , p. 5433-5439

7. T. MUKAI, S. TSUKUI, K. YOSHIDA, S. YAMAGUCHI, R. HATAYAMA, M. ADACHI, H. ISHIBASHI, Y. KAKEHI, K. SATOH, T. KUSAKA, K. C. GORETTA, Journal of Fuel Cell Science and Technology, 10, 2013, p. 061006-6

8. P. PLONCZAK, M. JOOST, J. HJELM, M. SØGAARD, M. LUNDBERG, P. V. HENDRIKSEN, Journal of Power Sources 196, 2011, p. 156-1162

9. B. SCHERRER, J. MARTYNCZUK, H. GALINSKI, J. G. GROLIG, S. BINDER, A. B. HÜTTER, J. L. M. RUPP, M. PRESTAT, L. J. GAUCKLER, Advanced Functional Materials, 22, 2012, p. 653-660

10. E. O. OH, C. M. WHANG, Y. R. LEE, S. Y. PARK, D. H. PRASAD, K. J. YOON, B. K. KIMC, J. W. SON, J. H. LEE, H.W. LEE, Ceramics International 40, 2014, p. 8135-8142

11. H. CHOI, G. Y. CHO, S.W. CHA, International Journal of Precision Engineering and Manufacturing-Green Technology, 2, 2014, p. 95-99

12. G. LAUKAITIS, D. VIRBUKAS, Solid State Ionics 247, 2013, p. 41-47

13. M. MISHRA, P. KUPPUSAMI, S. RAMYA, V. GANESAN, A. SINGH, R. THIRUMURUGESAN, E. MOHANDAS, Surface \& Coatings Technology 262, 2015, p.56-63

14. N. PRYDS, K. RODRIGO, S. LINDEROTH, J. SCHOU, Appl. Surf. Sci. 255, 2009,

p. $5232-5235$

15. K. MUTHUKKUMARAN, P. KUPPUSAMI, T. MATHEWS, E. MOHANDAS, S. SELLADURAI, Materials Science-Poland 3, 2007, p. 671-678

16. H. FUJIWARA, John Wiley \&Sons, 2007, p.170

17. L. GAO, F. LEMARCHAND, M. LEQUIME, Thin Solid Films 520, 2011, p. 501-509

18. D.V. LIKHACHEV, N. MALKOVA, L. POSLAVSKY, Thin Solid Films 589, 2015, p. 844-851

19. D.FRANTA, M. CERMÁK, J. VOHÁNKA, I.OHLÍDAL, Thin Solid Films 631, 2017, p.12-22

Manuscript received: 1.03 .2019 